\title{
Ground Water Quality of Areas Selected NE of Mousl City Used For Irrigration and Drinking Purposes
}

\author{
Taha Hussein Al-Salim \\ Remote Sensing Center
}

\section{Lilian Yaqup matte}

Environment and pollution control- Research Center University of Mosul

\begin{abstract}
The chemical characteristics of ground water samples in Bartelah and Ain Safra catchments area NE of Mosul city have been studied through chemical analysis of (11) water samples to evaluate the quality of ground water to determine its suitability for domestic and agricultural uses. Physical and chemical parameters of ground water samples such as $\mathrm{Ca}, \mathrm{Na}$, $\mathrm{Mg}, \mathrm{K}, \mathrm{HCO} 3, \mathrm{SO}_{4}, \mathrm{Cl}, \mathrm{NO} 3, \mathrm{Ec}, \mathrm{TDS}, \mathrm{pH}$, and (TH) were determined. Ion concentration is found to be directly related to environmental and hydrogeologic features.

Chemical parameters were analyzed graphically by means of contour maps for $\mathrm{Ca}, \mathrm{Na}$, $\mathrm{HCO}_{3}, \mathrm{SO}_{4}, \mathrm{Cl}$ and $\mathrm{Ec}$ to illustrate the spatial distribution of chemical constituents of the ground water.

Piper diagram is also used to show the suitability, type and the geochemical evolution of ground water. Richard and Wilcox classifications are also used to show the suitability of ground water for irrigation. that most ground water samples falls in the field of doubtful to unsuitable for irrigation except samples 7, 8 and 9 which they are fell in the field of good to permissible for irrigation.

Interpretation of analytical data shows that mixed cations-SO4 type, mixed cation$\mathrm{HCO} 3$ type and mixed $\mathrm{Ca}-\mathrm{Mg}-\mathrm{Cl}$ type are the dominant chemical faces. Ground water is generally hard, fresh to saline and low alkaline in nature.

Key words: Water quality, TDS, Cations, Anions, EC, Piper

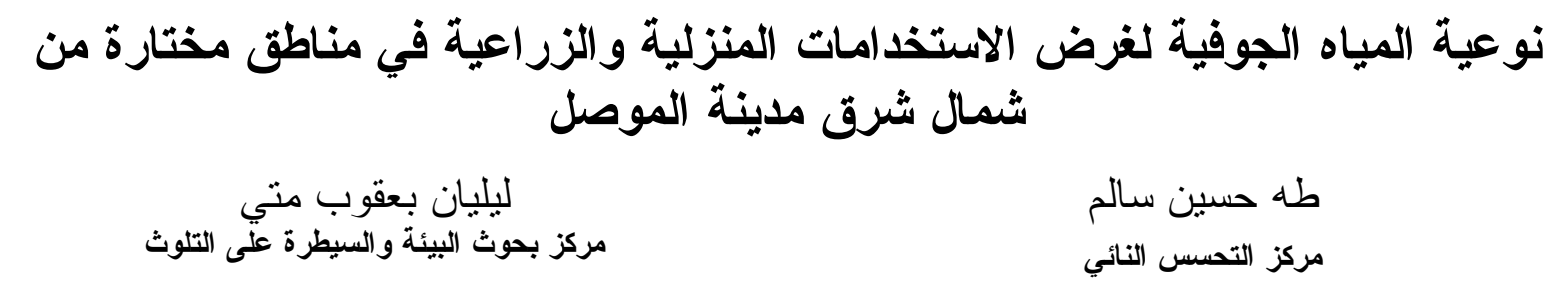

\section{الخلاصة}

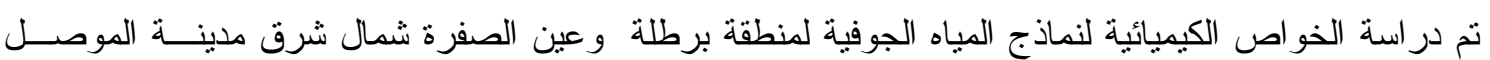

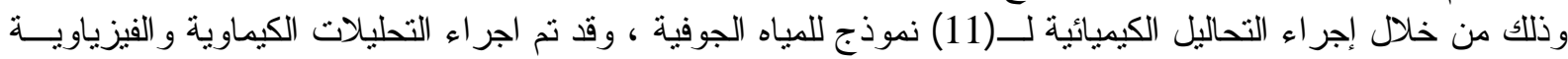

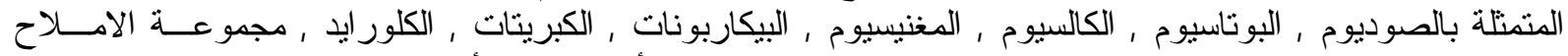

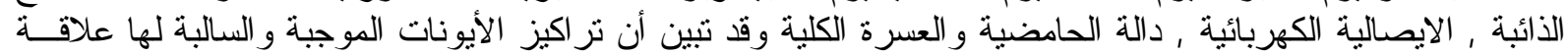

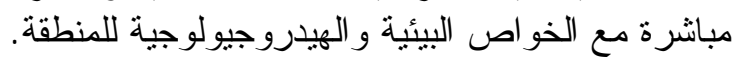
تم رسم خر ائط كنتورية لبعض البئية العو امل (

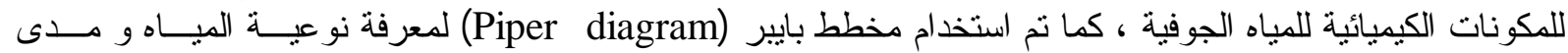

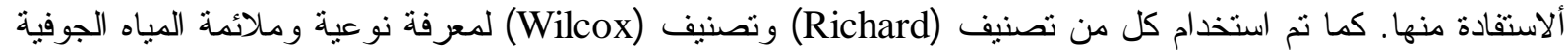

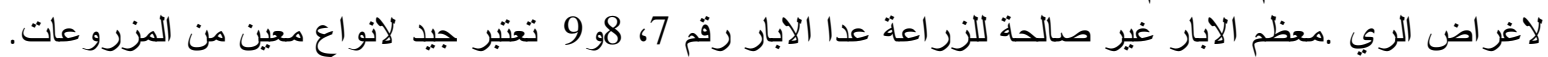

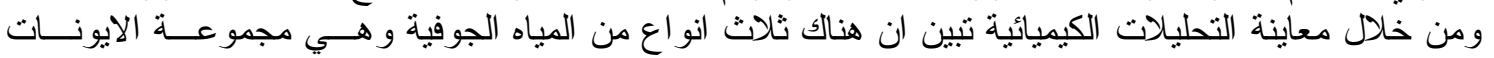

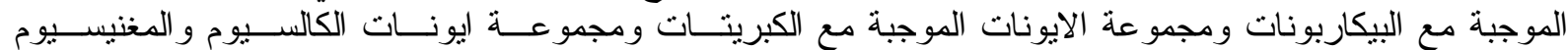
و الكلور ايد.تصنف المياه الجوفية بشكل عام فى هذه المنطقة كمياه عسرة ، عذبة الكية الى مالحة وقليلة القاعدية.
\end{abstract}




\section{Introduction}

Ground water quality is defined by the chemical constituents in the water and the chemical analysis data are helpful for determining the usefulness of ground water as a potable resource.

The studied area is located $20 \mathrm{Km}$ NE of Mosul city Fig. (1). It covers an area of about $120 \mathrm{Km}^{2}$. The climate of the area is of semi- arid type and receives an average rainfall of about $340 \mathrm{~mm} / \mathrm{year}$. Ain Safra PilaSpi anticline in the NE of the studied area forms the recharge area to the basin. Al Fatha Formation, an extensive aquifer, is overlain by flat- lying Quaternary sediments. Injana Formation crop out in the eastern part of the studied area.

Major ion chemistry is identified and the graphical representation of the hydrochemistry is used to identify the type of water and the distribution of major ion concentration of the area under research.

People and farm owners in this area resorted to drill their private wells and extract ground water to meet their domestic, agricultural and industrial needs .The future agricultural development in this area will be accompanied by increased demands for water which must come from local ground water resources.

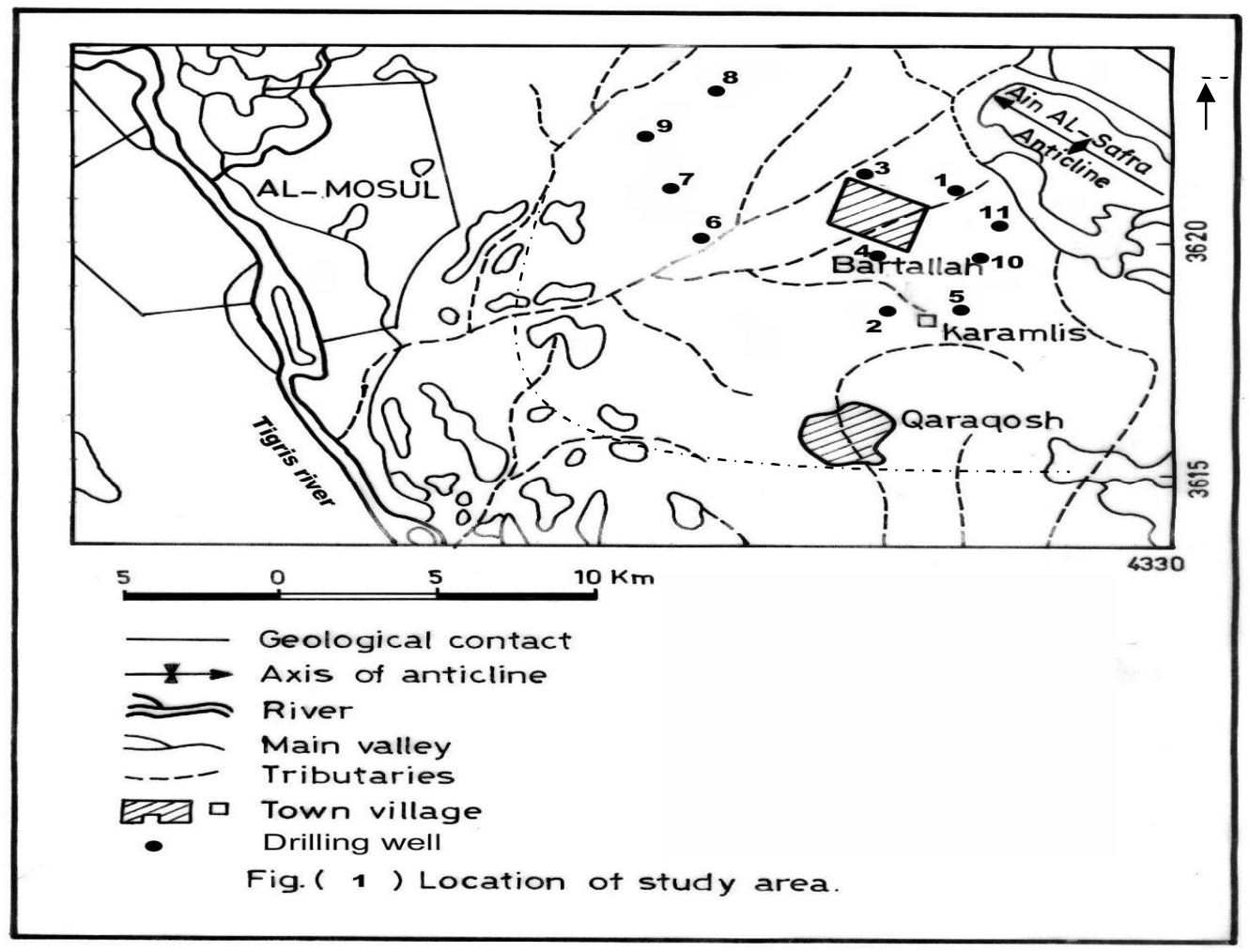

Fig (1) location of studv area

\section{Review \& Literature}

The quality of groundwater has recently begun to invoke considerable concern as the population has expanded and more water demands have to be provided.

Naturally occurring contaminants are present in the rocks and sediments. As ground water flows through sediments, metals such as iron and manganese are dissolved and may later be found in high concentrations in the water. Industrial discharges, urban activities, agriculture, ground-water pumpage, and disposal of waste all can affect ground-water quality. Contaminants from leaking fuel tanks or fuel or toxic chemical spills may enter the ground water and contaminate the aquifer. Pesticides and fertilizers applied to lawns and crops can accumulate and migrate to the water table ${ }^{[1]}$. 


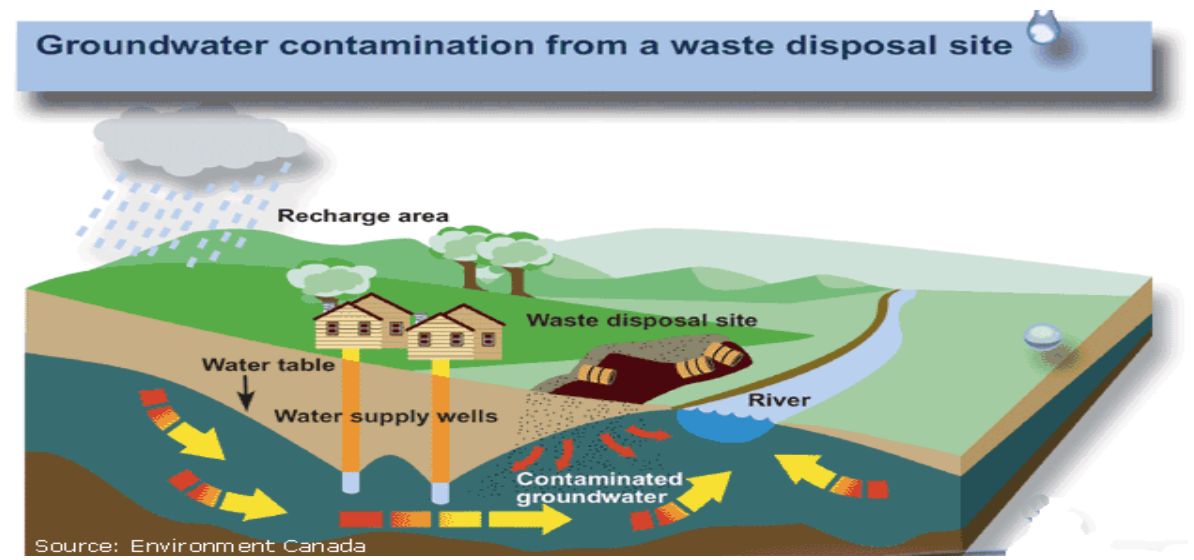

Hardness Result of metallic ions dissolved in the water; reported as concentration of calcium carbonate. Calcium carbonate is derived from dissolved limestone or discharges from operating or abandoned mines. Decreases the lather formation of soap and increases scale formation in hot-water heaters and low-pressure boilers at high levels ${ }^{[1]}$.

Generally groundwater has higher hardness than surface water. Tebutt ${ }^{[2]}$ defines soft water as that has less than $60 \mathrm{mg} / 1$ hardness as $\mathrm{CaCO}_{3}$ whereas very hard water would have more than $180 \mathrm{mg} / \mathrm{l}$.

The total dissolved solid contents in ground water may vary from $20 \mathrm{mg} / 1$ in area of high rainfall to over $100000 \mathrm{ppm}$ in some desert brines ${ }^{[3]}$.

Manganese occurs naturally as a mineral from sediment and rocks or from mining and industrial waste. Concentration up to $100 \mathrm{mg} / \mathrm{l}$ may be encountered, Hamil and bell reported that a concentration as high as $1500 \mathrm{mg} / \mathrm{l}$ may be considered harmless causes aesthetic and economic damage, and imparts brownish stains to laundry. Affects taste of water, and causes dark brown or black stains on plumbing fixtures. Relatively non-toxic to animals but toxic to plants at high levels ${ }^{[4]}$.

Based on public health service criteria ,sulfate concentration should not exceed $250 \mathrm{mg} / \mathrm{l}$ because the water will have Forms hard scales on boilers and heat exchangers; can change the taste of water, and has a laxative effect in high doses ${ }^{[5]}$.

The two most important measures for determining irrigation water quality are:

1. The total amount of dissolved salts in the water.

2. The amount of sodium $(\mathrm{Na})$ in the water compared to calcium $(\mathrm{Ca})$ plus magnesium $(\mathrm{Mg})$.

The total dissolved salt content is estimated by measuring how well the water conducts electricity. Salty water is a good conductor of electricity. Electrical Conductivity (EC) is measured in units of micromhos $/ \mathrm{cm}$ ( $\mu \mathrm{mhoms} / \mathrm{cm})$. The ppm salt concentration of the water is estimated by multiplying 0.65 times the EC value. Other analytical procedures are used to measure the amounts of individual chemicals, such as sodium, in the water. The chemicals routinely measured to determine irrigation water quality follow: Electrical Conductivity $(\mu \mathrm{mhos} / \mathrm{cm})$, Chloride $(\mathrm{Cl})$, Sodium $(\mathrm{Na})$,Nitrate (NO3), Calcium (Ca) ,Carbonate (CO3) ,Magnesium $(\mathrm{Mg})$,Bicarbonate (HCO3) Sulfate $(\mathrm{SO} 4)^{[1]}$.

Irrigation water quality can be understood by determining Sodium Adsorption Ratio (SAR) and Sodium Percentage (Na \%). SAR is defined by (Karanth 1987):

$$
S A R=\frac{N a}{\sqrt{\frac{C a+M g}{2}}}
$$

$\mathrm{Na} \%$ is calculated by using the following formula:

$$
\mathrm{Na} \%=\frac{\left(\mathrm{Na}^{+}+\mathrm{K}^{+}\right)}{\left(\mathrm{Ca}^{2+}+\mathrm{Mg}^{2+}+\mathrm{Na}^{+}+\mathrm{K}^{+}\right)} * 100
$$


The Piper diagram not only shows graphically the nature of a given water sample, but also dictates the relationship to other samples.To construct the Piper diagram, the relative abundance of cations with the $\%$ meq/ $\mathrm{L}$ of $\mathrm{Na}++\mathrm{K}+, \mathrm{Ca} 2+$, and $\mathrm{Mg} 2+$ is first plotted on the cation triangle. The relative abundance of $\mathrm{Cl}-$, SO42-, and $\mathrm{HCO} 3-+\mathrm{CO} 32-$ is then plotted on the anion triangle. The two data points on the cation and anion triangles are then combined into the quadrilateral field that shows the overall chemical property of the water sample ${ }^{[6]}$.

\section{Geology and water flow of surveyed areas}

The studied area is almost flat and slope generally from NE to SW. This flat land form range in elevation from (200) $\mathrm{m}$ to (220) $\mathrm{m}$ above sea level and dissected by drainage wadis as shown in fig. (2). the low plains can contain productive aquifers and are also, locally, areas of ground water discharge (Attia, 1994). Ain Safra anticline (composed of lime stone) to the North East of the study area, formed the upland recharge area to the aquifers and has elevation of (480) $\mathrm{m}$ above sea level and dissected by dry drainage wadis which become active during heavy precipitation.

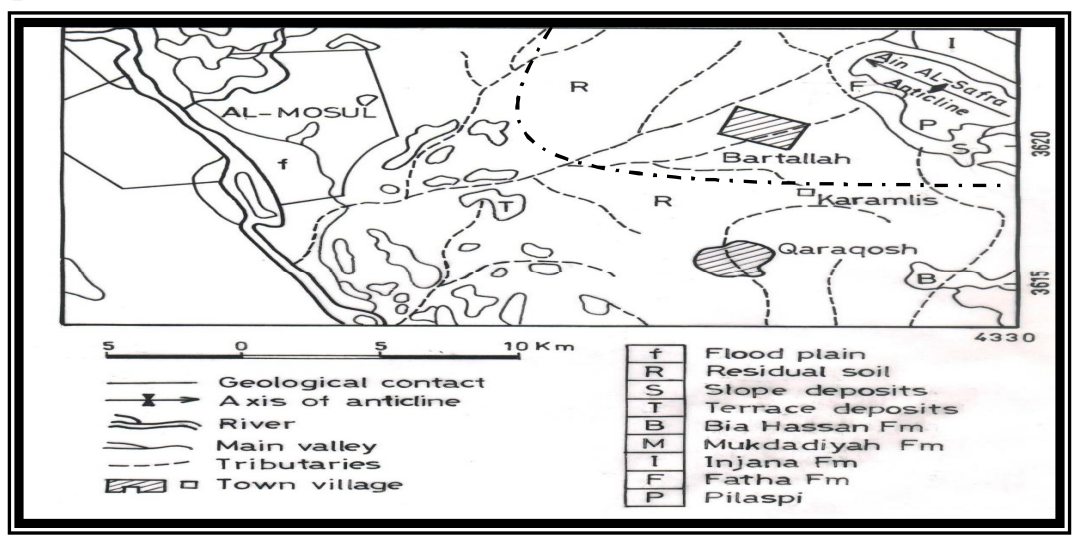

Fig (2) geology of study area

Ground water generally moves from topographically high areas where recharge occurs, to topographically low areas, where ground water discharges to stream and river. Topographic maps are useful for reviewing the location and distribution of surface features to determine the general direction of ground water movement.

A potentiometer map is constructed by (Al-Neiami, 2000) from water level elevations fig. (3). This ground water map was based on the static water levels recorded at different ground water well and shows the general ground water flow in the studied area to be in the direction of $\mathrm{NE}$ - SW. In general the water - table configuration is a replica of the topography. Water level contours indicate flow towards Tigris River.

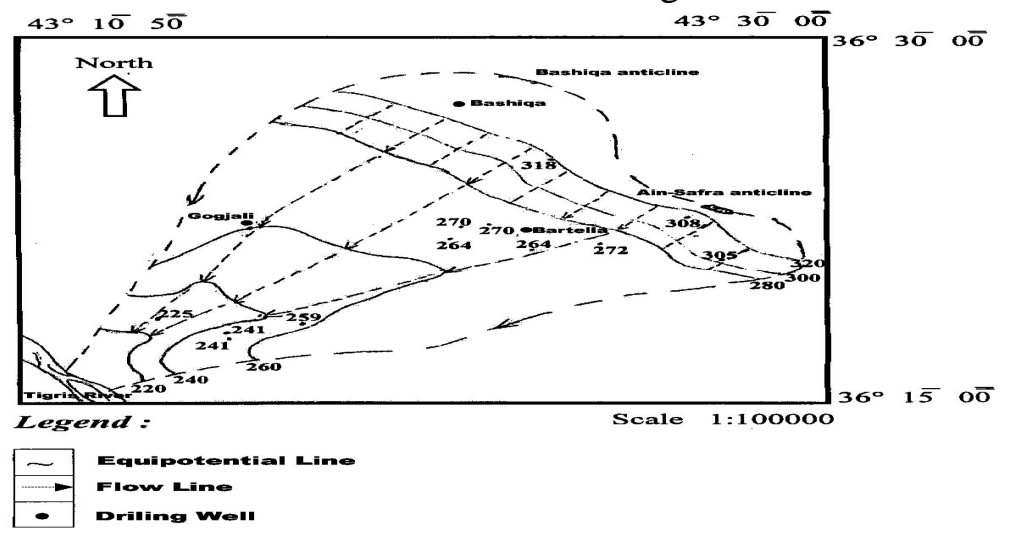

Fig (3) ground water flow of the study area (Al- Noiami, 2000) 


\section{Sample collection and analysis:}

The study of characteristics of ground water of the area under study is based on the results analysis of (11 well) samples. The chemical analysis of ground water sampled were carried out in the laboratories of the Environmental Research Center, Mosul University, all test were performed as conform to standard methods. samples are analyzed for major cations ( $\mathrm{Ca}, \mathrm{Na}, \mathrm{K}$, and $\mathrm{Mg}$ ) and major anions $\left(\mathrm{Cl}, \mathrm{SO}_{4}, \mathrm{HCO}_{3}\right.$, and $\mathrm{NO} 3$ ), $\mathrm{TH}, \mathrm{pH}, \mathrm{EC}$, and TDS.

The groundwater samples were collected during two periods of the year 2007. the first one in April 2007 where the ground water level is high and the second period was in October 2007. where the ground level was low, the analysis of the two periods shows a slightly different with concentration of chemical constituents of the samples, and the mean of these analysis are summarized in table (1).

Table (1) Ion concentration of ground water samples of the study area (ppm)

\begin{tabular}{|c|c|c|c|c|c|c|c|c|c|c|c|c|c|c|}
\hline sample & $\mathbf{C a}$ & $\mathbf{N a}$ & $\mathbf{K}$ & $\mathrm{Mg}$ & $\mathrm{HCO}_{3}$ & $\mathrm{SO}_{4}$ & $\mathrm{Cl}$ & $\mathbf{N O}_{3}$ & TDS & EC & pH & TH & SAR & $\mathrm{Na} \%$ \\
\hline 1 & 420.8 & 445 & 4.5 & 347.2 & 520 & 562.5 & \begin{tabular}{|l|}
529.8 \\
\end{tabular} & 12.4 & 2500 & $\begin{array}{l}3930 \\
\end{array}$ & 7.69 & 2479.4 & 5.3 & 22.64 \\
\hline 2 & $\begin{array}{l}581.9 \\
\end{array}$ & 570 & 2.8 & \begin{tabular}{|l|}
683.2 \\
\end{tabular} & 516 & 962.5 & \begin{tabular}{|l|}
389.8 \\
\end{tabular} & 2.9 & 3780 & 3340 & 7.76 & 4264.3 & 2.5 & 12.76 \\
\hline 3 & 380.7 & 256 & 2.5 & $\begin{array}{l}705.2 \\
\end{array}$ & 500 & 760. & 324 & 3.95 & 2315 & 2670 & 7.47 & 3854.1 & 3.3 & 15.18 \\
\hline 4 & 380.6 & 360 & 2.3 & 840.0 & 440 & 677.5 & 419.8 & 14.5 & 2822 & 3210 & 7.59 & 4406.9 & 4.9 & 19.65 \\
\hline 5 & 641.2 & 590 & 2.8 & 896 & 620 & 1800.5 & 529.8 & 13 & 5430 & 4865 & 7.37 & 5288.1 & 3.7 & 20.90 \\
\hline 6 & 360.7 & 310 & 2 & $\begin{array}{l}403.2 \\
\end{array}$ & 560 & 312.5 & 289.9 & 1.86 & 1860 & 2240 & 7.54 & 2559.8 & 1.8 & 14.04 \\
\hline 7 & 240.4 & 120 & 1.8 & 246.4 & 720 & 50 & 99.9 & 6.5 & 1620 & 1021 & 7.67 & 1614.2 & 0.89 & 6.2 \\
\hline 8 & 200.4 & 70 & 1 & 445 & 522 & 150 & 229.9 & 3.5 & 1622 & 802 & 7.51 & 2331.5 & 1.07 & 7.3 \\
\hline 9 & 260.5 & 85 & 1.2 & 419.7 & 580 & 75 & 239.9 & 9.3 & 1870 & 860 & 7.6 & 2377.5 & 3.8 & 20.80 \\
\hline 10 & 340.6 & 335 & 8.2 & 481.6 & 524 & 525 & \begin{tabular}{|l|l|}
489.8 \\
\end{tabular} & 6.5 & 2342 & 2640 & 7.85 & 2832.2 & 9.5 & 41.7 \\
\hline 11 & 300.6 & 740 & 3.5 & 369.6 & 540 & 262.5 & \begin{tabular}{|l|l|}
449.8 \\
\end{tabular} & 7 & 2220 & 2620 & 7.7 & 2271.5 & 5.5 & 28.27 \\
\hline
\end{tabular}

\section{Results \& Discussion}

\section{Mapping chemical Parameters:}

Chemical parameters are analyzed graphically by means of contour maps of $\mathrm{EC}, \mathrm{Ca}$, $\mathrm{Mg}, \mathrm{Na}, \mathrm{HCO}_{3}, \mathrm{SO}_{4}$ and $\mathrm{Cl}$ as shown in Fig. (4) To illustrate the spatial distribution of chemical constituents of the ground water. The influence area of ions distribution is at the synclinal part of Ain Safra Antclines and show that more than one potential source exist that could increase the salinity level of ground water.

\section{Ground Water Quality}

\section{Hydrochemical:}

Piper Diagram, (Hem. 1985) also is used to illustrate the major ions composition of ground water samples Fig. (5). this diagram is particularly useful for detecting changes or trends in ground water chemistry across an area or through time (Sanders 1998). Piper diagram shows that samples, 2,3,4,5 and 10 of mixed cations- $\mathrm{SO}_{4}$ type and samples 7, 9 of mixed cation- $\mathrm{HCO}_{3}$ type and samples $1,6,8$, and 11 of mixed $\mathrm{Ca}-\mathrm{Mg}-\mathrm{Cl}$ type.

\section{Water Quality for drinking:}

Tables (1) show that the T.H, T.D.S, $\mathrm{SO}_{4}, \mathrm{NO}_{3}, \mathrm{Mg}, \mathrm{Cl}$ in area study are ranging from (1614-5288), (1620-5430), (50-1800), (1.86-14.5), (347.2-896), (99.9-529.8) mg/l respectively. The suitability water for drinking has been based on comparing the results of the samples with WHO international show in table (2). Accordingly none of the well in studied areas agrees with that value. 
\begin{tabular}{llll} 
Al-Rafidain Engineering & Vol.17 & No.3 & June 2009 \\
\hline
\end{tabular}

$\mathrm{km}$
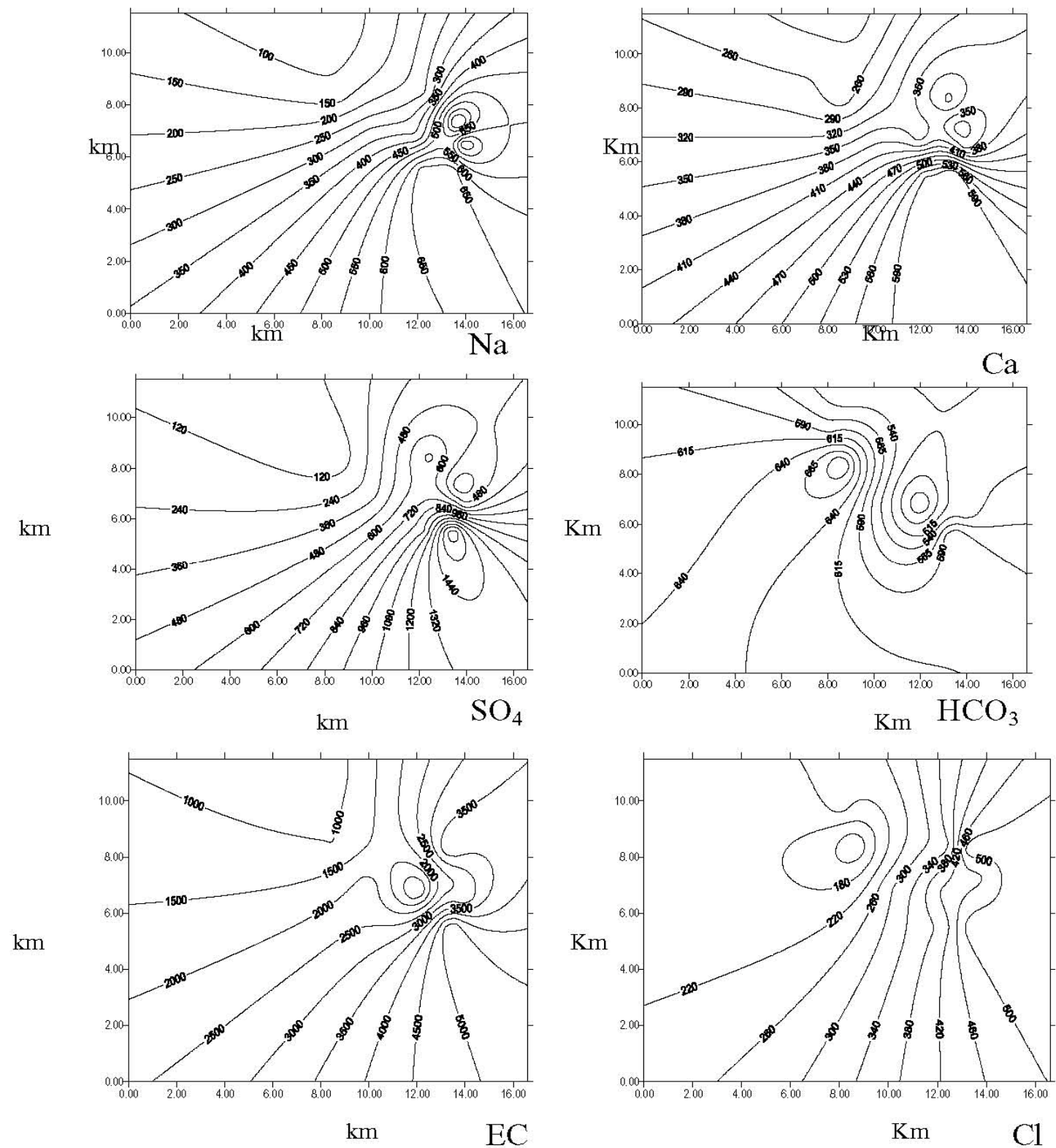

Fig. (4). Ion distribution on the study area.

Table (2) WHO international drinking water regulations ${ }^{[12]}$

\begin{tabular}{|c|c|c|}
\hline \multirow[t]{2}{*}{ parameter } & \multicolumn{2}{|c|}{ W.H.O } \\
\hline & Recommended mg/l & $\begin{array}{l}\text { Max } \\
\mathrm{mg} / \mathrm{l}\end{array}$ \\
\hline Chloride & 200 & 600 \\
\hline Magnesium & 年---- & 150 \\
\hline Nitrate & 6 & 11 \\
\hline Sulfate & 200 & 460 \\
\hline T.D.S & $\overline{500}$ & $15 \overline{1500}$ \\
\hline "T.H & 10 & 500 \\
\hline
\end{tabular}




\section{Water Quality for Irrigation:}

1-SAR is an important parameter for determining suitability of ground water for irrigation because it is a measure of alkali / sodium hazards to crops ${ }^{[13]}$. Plotting of SAR and electrical conductivity (Ec) on the US salinity diagram ( Richards 1954) Fig.(6) illustrate that ground water samples 6 and 7 fall in the field of C3S1, indicating high salinity and low Na water, samples 8 and 9 fall in the field C2S1 indicating medium salinity and low Na which can be used for irrigation. Ground water samples 3, 4 and 10 fall in the field of C4S1, indicating very high salinity and low alkalinity hazard. This can be suitable for plants having good salt tolerance and also restricts their suitability for irrigation. Samples 1, 2, 5 and 11 fall in the field of very high salinity and medium $\mathrm{Na}$ which can not be used for irrigation.

2- The plot of $\mathrm{Na} \%$ and total concentration of ions on the Wilcox (1955) diagram Fig.(7) shows that most of the ground water samples fall in the field of doubtful and unsuitable for irrigation except samples 7,8 and 9 falls in the field of good to permissible for irrigation. High concentration of sodium in water reduces soil permeability.

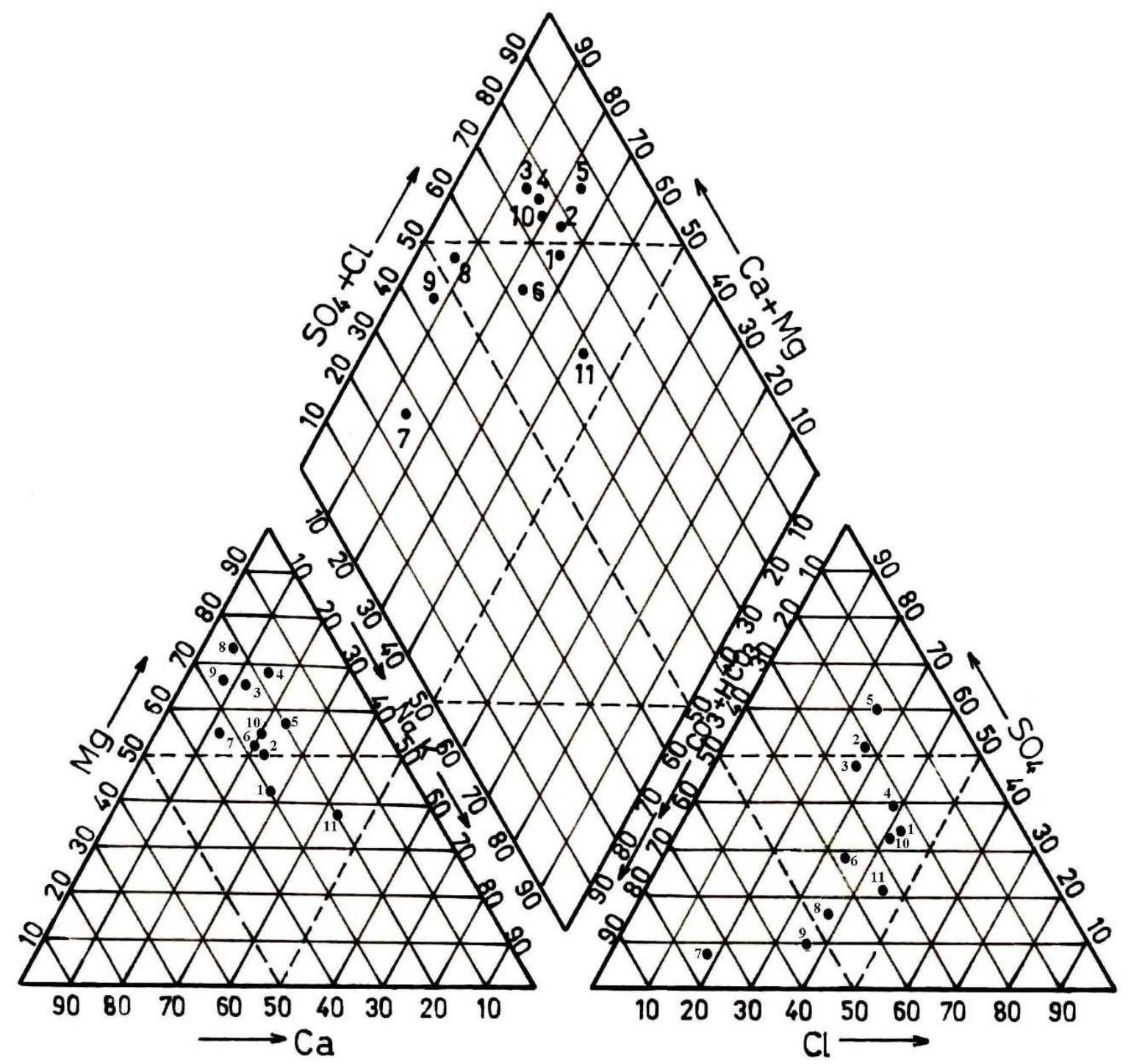

Fig. (5) piper Diagram. 


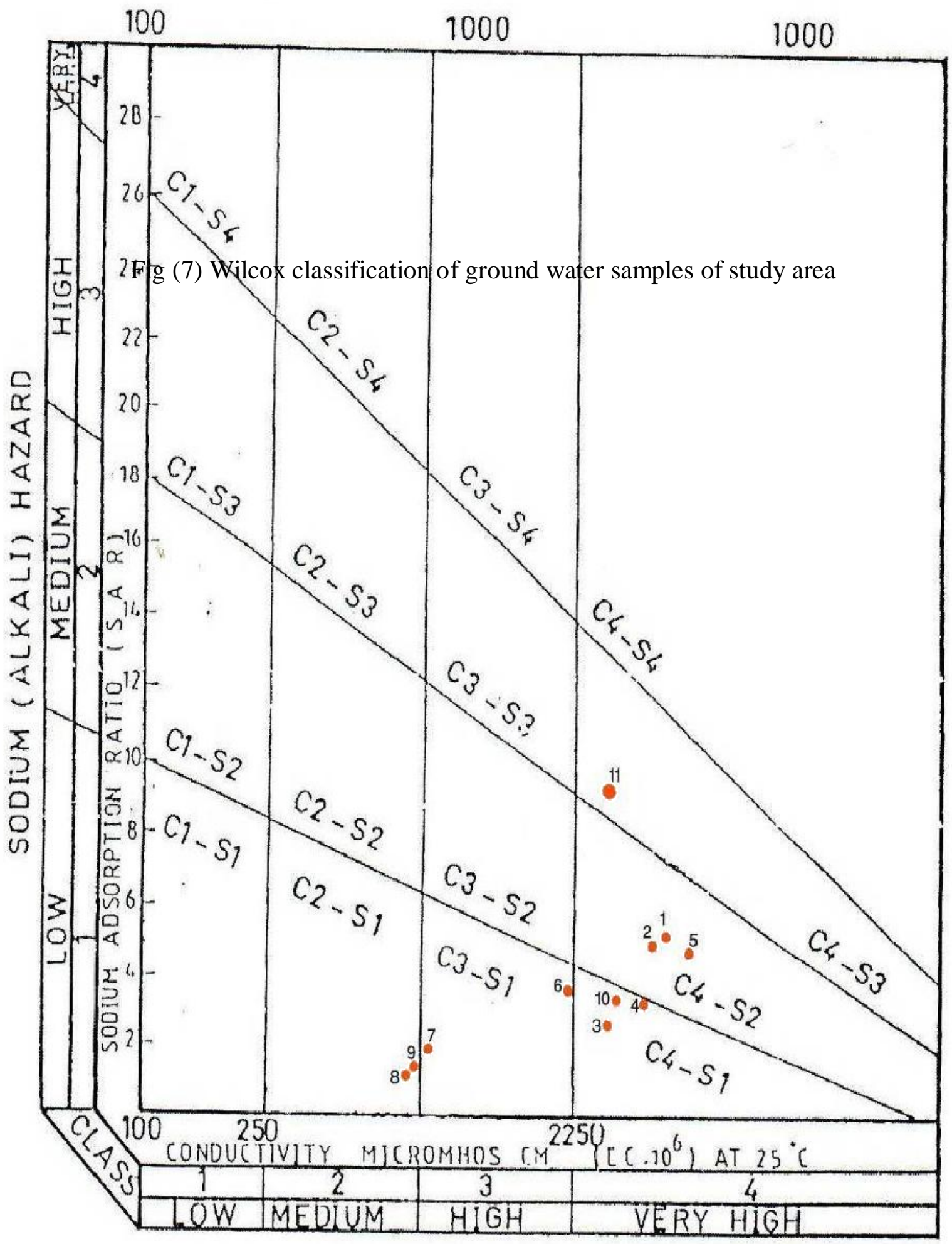

SALINITY HAZARD

Fig (6) Richard classification of ground water samples of study area 


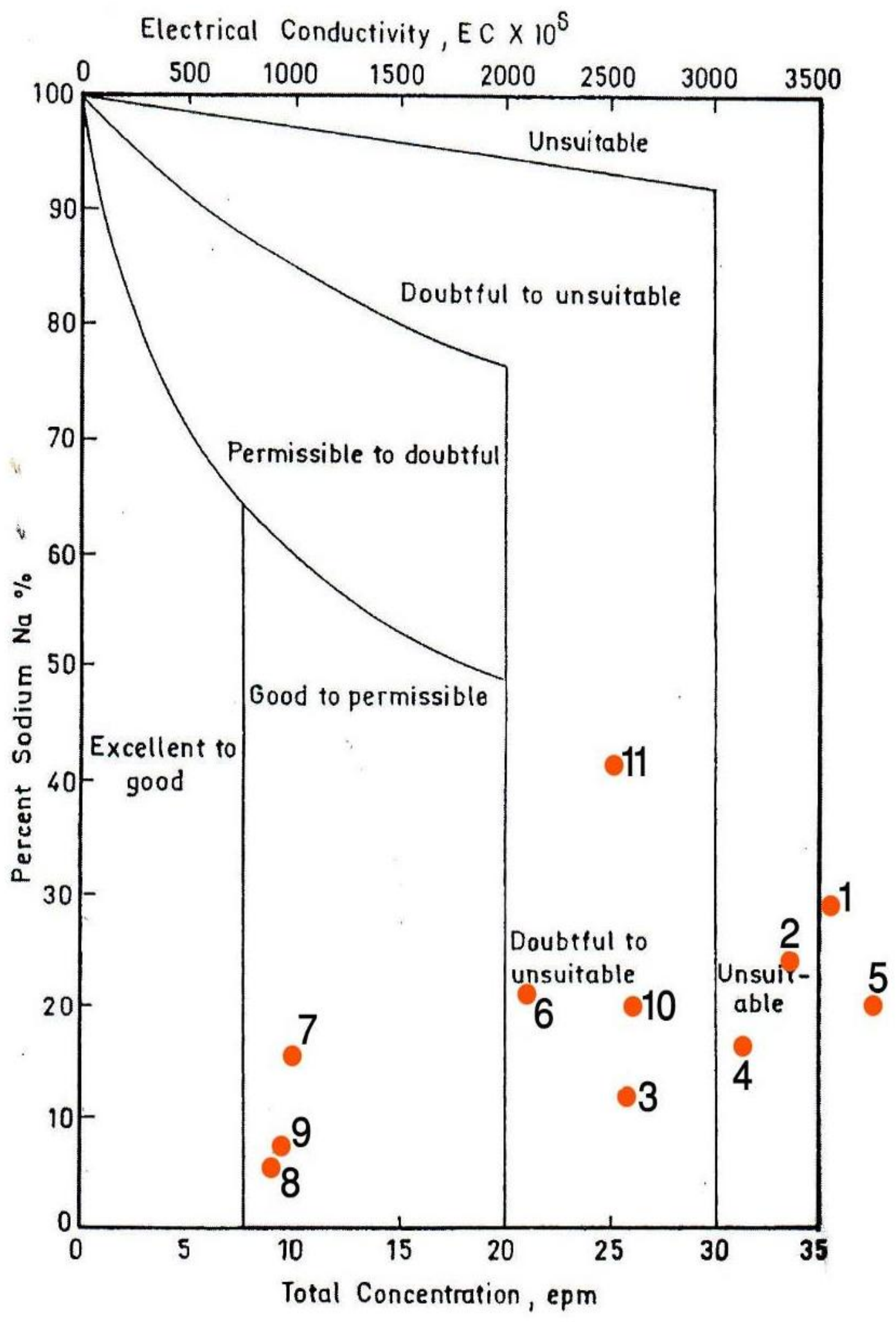

Fig (7) Wilcox classification of ground water samples of study area 


\section{Al-Rafidain Engineering \\ Vol.17 No.3 \\ June 2009}

\section{Conclusion}

This research gives a guide lines for the suitability of ground water for domestic and agricultural purposes.

1-Al-Fatha formation contain sufficient gypsum or anhydrite, and as a result of contact between water and minerals of this formation, leads to the increase of TDS and sulfate concentration.

2-Interpretation of the results of chemical analysis, taking in to consideration the available geological and hydrogeological information, reveals that the ground water is hard, fresh to saline and alkaline in nature.

3-Total hardness (TH) is generally high in the ground water samples there by, causing most ground water samples in the study area to be unsuitable for drinking.

4- Piper diagram shows that ground water samples 7 and 9 fall in the field of mixed cation HCO3 and samples 2,3,4,5 and 10 fall in the field of mix catio - SO4, while samples 1,6 ,8 and 11 fall in the field of mixed $\mathrm{Ca}-\mathrm{Mg}-\mathrm{Cl}$ type of water.

5- According to the Richard salinity hazard most samples fall in the field of very high salinity and medium sodium which can not be used for irrigation, samples 6 and 7 fall in the field of high salinity and low sodium which can be used for plants having good salts tolerance and restricts its suitability for irrigation, and samples 8 and 9 are found to be suitable for irrigation because of its medium salinity and low sodium.

6- Wilcox classification shows that most ground water samples falls in the field of doubtful to unsuitable for irrigation except samples 7,8 and 9 which they are fell in the field of good to permissible for irrigation.

\section{References}

1- USGS, water science for schools ground water quality .htm

2- Tebutt T .H .Y, "Relationship between natural water quality and health" Unesco paris 1983.

3- Karanth, K.R. (1987) Ground water assessment, development and management. Tata McGraw Hill, New Delhi, pp720.

4- Hamil 1 and F.G .Bell "Groundwater, Resources, Development" Butterworth England 1983

5- Puplic Health Service "Drinking water standards" .U.S. Dept of health, education and welfare. Washington D.C 1962.

6- Rock ware Earth Science and GIS Software http://www.rockware.com

7- Attia, F. A. R, Ground water quality in the Nile aquifer system and desert fringes in Egypt. Ground water quality J. Edited by H. Nash and G. J. H. McCall, pp 123-129, 1994.

8- Al-Neiami, F.H.,"Hydrogeology of Wadi Al-Shour".Unpub.Msc. thesis,Univ.of Mosul .Collage of Science, 2000 .

9- Standard Methods for the Examination of water and wastewater" American public Health Association, $14^{\text {th }}$ Edition, 1985.

10 - Hem,J.D, "Study and interpretation of the chemical characteristics of natural water", $2^{\text {nd }}$ ed. U.S. Geological Survey water -supply paper ,473,363pp, 1985.

11-Sanders, L.L. "A manual of field hydrogeology", Prentice -Hall, Inc, 1998.

12- WHO: World health, Geneva December 1986.

13-Richard, L.A. "Diagnosis and improvement of saline alkali soils" US Department of Agriculture, Hand Book 60, pp 160, 1954.

14-Wilcox, L.V. "Classification and use of irrigation waters". USDA, Circular 969, Washington, DC, USA1955.

The work was carried out at the college of Engg. University of Mosul 